\title{
Determination of amino acid and fatty acid composition of goldband goatfish [Upeneus moluccensis (Bleeker, 1855)] fishing from the Gulf of Antalya (Turkey)
}

\author{
Güntekin Doğan (1) O Ömer Osman Ertan
}

Received: 12 March 2017/ Accepted: 23 September 2017/Published online: 30 September 2017

(C) The Author(s) 2017. This article is an open access publication

\begin{abstract}
In this study, we aimed to determine the basic food components, fatty acids and amino acids, and variations in these components with months in goldband goatfish (Upeneus moluccensis) that fishing from Gulf of Antalya. As a result of the analyzes, the crude fat values were determined between 1.43 and 3.78\%, and the crude protein values were determined between 20.79 and $22.16 \%$. The most abundant fatty acids were determined: palmitic acid (C16:0), stearic acid (C18:0), palmitoleic acid (C16:1c9), oleic acid (C18:1c9), linoleic acid (C18:2n-6), eicosatrienoic acid (C20:3n-3), arachidonic acid (C20:4n-6), eicosapentaenoic acid (C20:5n-3), docosapentaenoic acid (C22:5n-6), and docosahexaenoic acid (C22:6n-3). The most abundant amino acids were determined lysine and leucine, aspartic acid, glutamic acid, alanine, and glycine. The differentiations of essential nutrient components, fatty acids, and amino acids were found generally significant $(P<0.05)$.
\end{abstract}

Keywords Goldband goatfish · Upeneus moluccensis - Fatty acids · Amino acids · Food components · Catching season

\section{Introduction}

Seafood is a highly valuable food source because of rich in protein, amino acid, unsaturated fatty acid (especially omega-3), and vitamin components which are necessary for healthy and balanced nutrition (Gulyavuz and Unlusayın 1999; Simsek et al. 2009). The taste of fish meat is closely related to the protein and fat content, and also the seasonal variations of these components are important determinant of both consumer choice and quality of the processed product. Depending on the season, water temperature and nutrients in the environment affect the biochemical composition of fish meat (Kuzu 2005). In many studies, the relationship between seasonal changes and the chemical composition of fish meat has been shown (Ersoy 2006; Kandemir and Polat 2007; Polat et al. 2009; Ozogul et al. 2011). In a study, it was emphasized that the chemical composition of different fish species depends on variables such as seasonal change, migration, sexual maturity, and nutrient cyclicity (Kuzu 2005).

\footnotetext{
G. Doğan $(\bowtie)$

Suleyman Demirel University, Isparta, Turkey

e-mail: guntekin32@hotmail.com

Ö. O. Ertan

Department of Fisheries Basic Sciences, Egirdir Fisheries Faculty, Suleyman Demirel University, Isparta, Turkey
} 
Scientific studies in various fields reveal that nutrients and nutritional habits play an important role in some diseases that people are confronted with, and the necessity of more conscious nutrition is needed. A number of studies have been undertaken to elucidate the positive effect of fish consumption on human health and to investigate the therapeutic properties of eicosapentaenoic acid (EPA) and docosahexaenoic acid (DHA) found in seafood (Broughton et al. 1997; Haris 1997; Conquer et al. 2000; Norrish et al. 2000; Ozkan and Koca 2006; Ebbesson et al. 2008). EPA and DHA must be taken as essential fatty acids from the outside for a healthy life (Canbulat and Ozcan 2008).

Amino acids are determinants of quality in fish and crustaceans (Ruiz-Capillas and Moral 2001). Most amino acids such as glutamic acid, aspartic acid, alanine, and glycine are important, because they are responsible for the taste and flavor (Ruiz-Capillas and Moral 2004). Sea food is important source of protein because of the high content of aspartic acid, glutamic acid, lysine, arginine, and leucine (Rosa and Nunes 2003; Erkan and Ozden 2007). In fish, 50-80\% of the non-protein nitrogenous compounds are amino acids and significant amounts of these are proline, arginine, lysine, alanine, histidine, glutamic acid, and taurine (RuizCapillas and Moral 2001; Ozden 2005). The most consumed and delicious portions of fish are muscle tissue and they contain plenty of flavor amino acids. Amino acids provide tissue healing and growth (Oluwaniyi et al. 2010).

Although some studies have been published (Celik et al. 1999; Ersoy 2006; Simsek et al. 2009; Oksuz et al. 2011) about the fatty acid and the basic food components of the goldband goatfish (Upeneus moluccensis), but no information was found about the amino acid composition and seasonal study about the fatty acid and the basic food components of the goldband goatfish. In this study, the seasonal variation of the basic food components, amino acids, and fatty acids in goldband goatfish which were caught during the fishing season in Gulf of Antalya and have economic importance was investigated.

\section{Materials and methods}

Providing and preservation of samples

Sampling were conducted monthly during the catching season (September, October, November, December, January, February, March, and April). The goldband goatfish (Upeneus moluccensis) samples were purchased sufficient quantity at the time of reaching on port as the freshest state and brought to the Food Processing Laboratory of Egirdir Fisheries Faculty under cold chain conditions in 2 h. First, total length and weight measurements were determined and viscera were removed. The samples to be used in the determination of nutrient components were packed in the amount required for each analysis and stored at $-80 \pm 1{ }^{\circ} \mathrm{C}$. 32 samples were used for each month. Female and male fish sample numbers were not considered.

Determination of the basic food components

Moisture analyzes of the samples were determined triplicate $(n=3)$ by an automatic moisture analyzer (AND MX-50 Moisture Analyzer, Japan). Crude ash analyzes were made triplicate $(n=3)$ according to AOAC (2002a), 920.153 Method. Crude protein analyzes were made duplicate $(n=2)$ according to AOAC (2010), 960.52 Micro Kjeldahl Method in the Turkey Scientific and Technical Research Institute Marmara Research Center (TUBITAK MAM).

Crude fat analyzes were made triplicate ( $n=3$ ) according to Lovell (1981). The glass containers to be used in the analyzes were first fixed weight. $5 \mathrm{~g}$ of sample placed in the tube were homogenized in a homogenizer (WiseTis HG-15D, Korea) with chloroform (Riedel-de-Haen, 24216), methanol (Riedel-de-Haen, 24229), and distilled water. The tubes were centrifuged (Sigma 2-16 K, Germany) at $3000 \mathrm{rpm}$ for $10 \mathrm{~min}$. At the end of the centrifugation, the methanol and water phase at the top, the fish meat phase in the middle, and the chloroform phase containing fat at the bottom were formed in the tubes. $1 \mathrm{~mL}$ was pipetted from the bottom chloroform phase and placed in fixed weight glass containers and evaporated in a hot water bath (WiseBath, Korea) for $1 \mathrm{~h}$ at $80^{\circ} \mathrm{C}$. At last cooled to room temperature in the desiccator and weighed on a precision scale and the amount of crude fat was determined as $\%$. 
Determination of fatty acids

Fatty acid analyzes were made duplicate $(n=2)$ in Suleyman Demirel University (SDU) Experimental and Observational Student Research and Application Center. Fat extractions were made according to Bligh and Dyer (1959), methyl ester analyzes of fatty acids were made according to AOAC (2002b), 996.06 Method using gas chromatography (GC, Perkin Elmer Auto System XL, USA). After identifying 37 standard locations, Supelco 18919 F.A.M.E. Mix C4-C24, was injected into the GC. The fatty acids of the samples were determined in the reference assay conditions of AOAC 996.06.

Determination of amino acids

The amino acid analyzes of the samples were made duplicate $(n=2)$ in TUBITAK MAM according to Dimova (2003), and Gheshlaghi et al. (2008), using the high-performance liquid chromatography (HPLC) method. This method is based on the reading of ultra fast liquid chromatography-ultraviolet (UFLC-UV) detector by derivatization with phenyl isothiocyanate and acetonitrile:methanol:triethylamine solution after acidic hydrolysis applied to disassociate the constituent proteins into amino acid components. Tryptophan is completely disappeared as a result of acid hydrolysis; for that reason, tryptophan analyzes were made by base hydrolysis method. The sulfur-containing amino acids immediately expose to degradation when hydrolyzed with a strong acid solution, so sulfur-containing amino acids did not determine. Totally, 17 amino acids (aspartic acid, glutamic acid, serine, glycine, arginine, histidine, threonine, lysine, alanine, proline, leucine, isoleucine, tyrosine, phenylalanine, valine, methionine, and tryptophan) were determined as $\mathrm{mg} / 100 \mathrm{~g}$.

Statistical analyzes

The data, obtained in the study, were subjected to analysis of variance ( $F$ test) using the SPSS 16.0 program. Averages of significant variance sources were compared using the Duncan multiple comparison test as significance level $P=0.05$.

\section{Results and discussion}

Average length and weight values

The monthly average of total length values was determined between $13.15 \pm 0.12 \mathrm{~cm}$ and $14.89 \pm 0.20 \mathrm{~cm}$, and the monthly average weight values were determined between $24.98 \pm 1.31 \mathrm{~cm}$ and $33.67 \pm 1.34 \mathrm{~g}$ (Table 1). We intended that purchased fish should be about the same length and weight each month when sampling is being done. However, it was observed that the average length and weight values of fish purchased in September, February, and April were higher than the other months, depending on the fishing month, fishing area, feeding regime, and spawning season.

Proximate analyzes

\section{Moisture}

In our study, the moisture values of $U$. moluccensis samples were found between $78.74 \pm 0.32$ and $80.30 \pm 0.45 \%$, and there was no significant $(P>0.05)$ difference detected in monthly moisture change rates (Table 2).

The moisture content of seafood varies greatly with species, sex, and age. It is generally the moisture contents found between 70 and $85 \%$ in fish. This ratio decreases to $50-60 \%$ in some fishes (Gulyavuz and Unlusayın 1999). In the previous studies, the moisture contents of Mullus barbatus were determined 59.75\% by Guner et al. (1998), 79.71\% by Kalogeropoulos et al. (2004), and $79.00 \%$ by Gumus et al. (2009). Erkan et al. (2010b) determined the humidity value $70.25 \%$ in Mullus surmuletus. Oksuz et al. (2011), determined the humidity values $79.41 \%$ in Upeneus moluccensis and $73.14 \%$ in M. surmuletus. Ersoy (2006), found the 


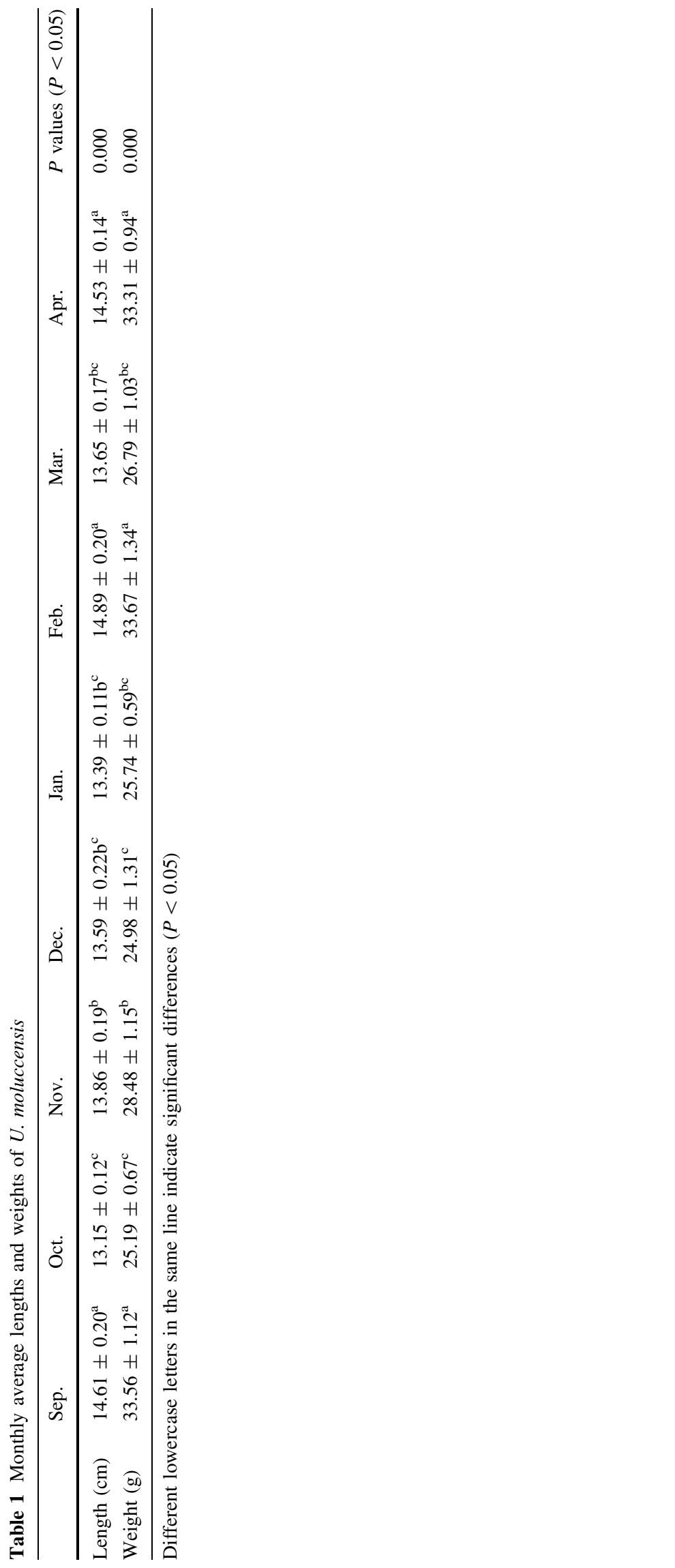




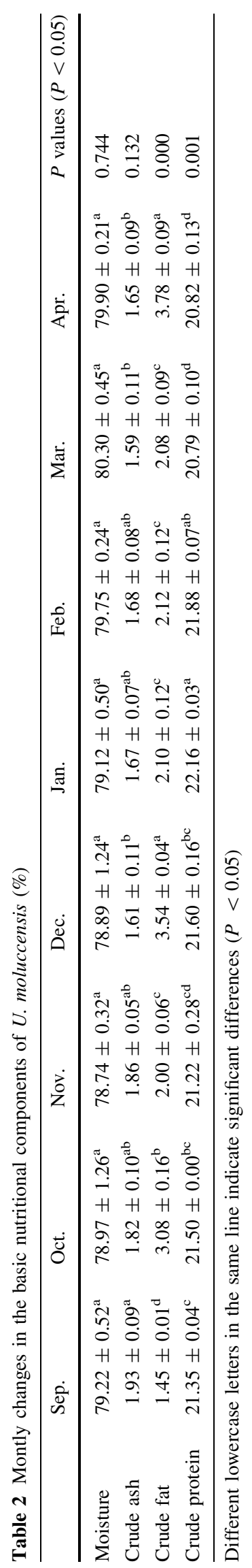


content of moisture in U. moluccensis between 75.79 and 78.27\% in September, December, March, and May, and he indicated that these changes originated from the fish diet. Polat et al. (2009), found the changes in moisture content of M. barbatus in Autumn, Winter, and Spring seasons 74.13-75.21 and 73.84\%, respectively, and they indicated that this changes originated from the feeding regime. Ozogul et al. (2011) investigated the changes in moisture content of Upeneus pori and M. barbatus seasonally. They determined the moisture contents between 75.31 and $79.08 \%$ in $U$. pori and between 76.23 and $76.92 \%$ in M. barbatus.

The moisture values were compared with the previous studies, it was observed that similar results were obtained in some studies (Kalogeropoulos et al. 2004; Gumus et al. 2009; Oksuz et al. 2011), and we found higher values than some studies (Guner et al. 1998; Erkan et al. 2010b; Polat et al. 2009; Tulgar and Berik 2012). We considered that the moisture value differentiations depend on species, season, nutritional regime, size, spawning season, sex, and catching area.

\section{Crude ash}

In our study, the crude ash was found between $1.59 \pm 0.11$ and $1.93 \pm 0.09 \%$. The highest crude ash was determined in September, and the lowest crude ash was determined in March (Table 2).

Gulyavuz and Unlusayın (1999) stated that the amount of inorganic matter in fish meat is about 1-2\%. Aquatic organisms take inorganic materials from food and water, and store them in skeletal tissue and other members. There are many factors affecting the amount of inorganic matter such as season, biological difference (species, length, age, sex, and sexual maturity), nutrition, and environmental conditions (water chemistry, temperature, and salinity) (Cakli 2007). In the previous studies, the crude ash contents of $M$. barbatus were found $0.90 \%$ by Guner et al. (1998) and $1.45 \%$ by Gumus et al. (2009). Erkan et al. (2010b) determined the crude ash content $1.10 \%$ in M. surmuletus. Oksuz et al. (2011) found the crude ash content $1.10 \%$ in U. moluccensis and $1.60 \%$ in M. surmuletus and they were indicated that the difference is due to the mineral content of the species. Ersoy (2006) found the crude ash contents in the U. moluccensis, caught in September, December, March, and May, 1.29, 1.35, 1.24, and 1.38\%, respectively. Polat et al. (2009) found that the crude ash contents of M. barbatus were $1.11 \%$ in Autumn, $1.09 \%$ in Winter, and $1.24 \%$ in Spring and they determined that seasonal variations were significant $(P<0.05)$. Ozogul et al. (2011) found the crude ash contents of $U$. pori between 1.42 and $1.65 \%$ and the crude ash contents of $M$. barbatus between 1.23 and $1.66 \%$.

When we compared our values with the previous studies, we found that crude ash values are higher than the previous studies due to species, nutritional regime, and hunting area. In some studies (Polat et al. 2009; Oksuz et al. 2011; Tulgar and Berik 2012), seasonal variations were found generally significant $(P<0.05)$. We also found monthly variations generally significant $(P<0.05)$ and we thought that the monthly differences in our study depend on the spawning season, size, nutritional status, and catching area.

\section{Crude fat}

In our study, it was determined that the crude fat contents changed between $1.45 \pm 0.01$ and $3.78 \pm 0.09 \%$. The highest crude fat content was determined in April, before the spawning season, and the lowest crude fat was determined in September, after spawning season. The crude fat values were detected significantly $(P<0.05)$ higher in April and December and significantly $(P<0.05)$ lower in September than the other months (Table 2). We thought that the distinction in crude fat contents depends mainly on the spawning season, age, sex, and nutritional density.

In fish, the amount of fat may be below $1 \%$ and may exceed $30 \%$ according to the species and biological status and the fish are grouped according to the fat content (Cakli 2007). In addition, the fat content changes depending on the age, sex, catching season, nutritional status, and living environment (Gulyavuz and Unlusayın 1999).

In the previous studies, the crude fat contents of M. barbatus were determined $9.72 \%$ by Guner et al. (1998), 3.52\% by Kalogeropoulos et al. (2004), and $1.75 \%$ by Gumus et al. (2009), and they considered them as low-fat fish. Celik et al. (1999) found that crude fat content was $6.67 \%$ in M. barbatus, $2.67 \%$ in M. surmuletus, and $4.91 \%$ in $U$. moluccensis. Erkan et al. (2010b) determined the crude fat content $14.46 \%$ in $M$. surmuletus. Oksuz et al. (2011) found that crude fat content was $4.35 \%$ in U. moluccensis and $10.38 \%$ in M. 
surmuletus in their study. They noted that although the species belong to the same family and the same habitat, they may have distinct fat content. Ersoy (2006) investigated the nutrient composition of U. Moluccensis caught in September, December, March, and May and she determined the crude fat contents as 3.26, 0.64, 2.20, and $0.51 \%$, respectively. Polat et al. (2009), in their study, determined the crude fat content of $M$. barbatus $3.68 \%$ in Spring, 5.33\% in Winter, and 5.76\% in Autumn. They thought that the fall in crude fat content during the spring season was to be due to the supply of raw energy needed for egg development during gonadogenesis formation, which reached the highest point just before the spawning. Ozogul et al. (2011) studied seasonally changes in crude fat content of $U$. pori and M. barbatus in their study. They determined the crude fat contents of $U$. pori between 1.07 and $2.10 \%$ and the crude fat contents of $M$. barbatus between 1.07 and $3.00 \%$. They argued that the changes in fat rates are due to the season of feeding and spawning.

When we compared the fat content with the previous studies, we found similar results in some studies (Celik et al. 1999; Kalogeropoulos et al. 2004; Ersoy 2006; Gumus et al. 2009; Ozogul et al. 2011) and higher results in some studies (Guner et al. 1998; Erkan et al. 2010b; Oksuz et al. 2011). In general, significant $(P<0.05)$ variations were determined in seasonal studies (Polat et al. 2009; Tulgar and Berik 2012). We also found monthly variations generally significant $(P<0.05)$. We determined the $U$. moluccensis in the low-fat fish class according to the Cakli (2007).

\section{Crude protein}

In our study, we determined the crude protein content between 20.79 and $22.16 \%$. The highest crude protein was determined in January, and the lowest crude protein was determined in March and April when the spawning period was near. Crude protein was detected in January significantly $(P<0.05)$ higher than other months, while crude protein values were detected in March and April significantly $(P<0.05)$ lower (Table 2). We thought that the differences in crude protein are mainly due to spawning season and nutritional density.

Gulyavuz and Unlusayin (1999) reported that the protein content of fish meat is about 14-20\%, and this values changes with age, gender, feeding environment, spawning, and migration season. Cakli (2007) also reported that protein contents of aquatic organisms are about 11-25\%. In the previous studies, the crude protein contents of $M$. barbatus were determined $16.3 \%$ by Guner et al. (1998), $14.79 \%$ by Kalogeropoulos et al. (2004), and $14.84 \%$ by Gumus et al. (2009). Celik et al. (1999) found crude protein contents $21.32 \%$ in M. barbatus, $19.56 \%$ in M. surmuletus, and $20.32 \%$ in U. moluccensis. Erkan et al. (2010b) determined the crude protein content $14.07 \%$ in M. surmuletus. Ersoy (2006) investigated the nutrient composition of the $U$. moluccensis fillets in September, December, March, and May and determined crude protein contents as 19.32, $21.00,18.75$, and $19.36 \%$, respectively. She stated that the protein contents changed depending on the catching season and the feeding density. Polat et al. (2009) found that the crude protein content of M. barbatus was $20.43 \%$ in Spring, $17.90 \%$ in Winter, and $18.97 \%$ in Autumn. The amount of crude protein in the spring, before spawning period, was significantly higher than other seasons $(P<0.05)$. Ozogul et al. (2011) found that the crude protein contents of $U$. pori were between 17.68 and $21.27 \%$ and the crude protein contents of $M$. barbatus were between 18.25 and $20.52 \%$ in their studies. They found the lowest protein contents in both species in Spring.

When we compared the our protein values with the previous studies, similar results were appeared in some studies (Celik et al. 1999; Ersoy 2006) and lower protein values were appeared in some studies (Guner et al. 1998; Kalogeropoulos et al. 2004; Gumus et al. 2009; Tulgar and Berik 2012). In seasonal studies (Ersoy 2006; Polat et al. 2009; Ozogul et al. 2011; Tulgar and Berik 2012), generally significantly $(P<0.05)$ different values were determined as our monthly study. When we examined the crude protein values of the $U$. moluccensis in our study, we concluded that it was an important protein source in all months (although the protein contents decreased in March and April when the spawning season approached).

\section{Fatty acids}

In our study, it was observed that the monthly variations of fatty acid values of $U$. moluccensis samples are generally significant $(P<0.05)$. We found that the most abundant fatty acids were palmitic acid and stearic acid as saturated fatty acids, palmitoleic acid and oleic acid as monounsaturated fatty acids, eicosatrienoic acid, arachidonic acid, EPA, and DHA as polyunsaturated fatty acids (Table 3). 


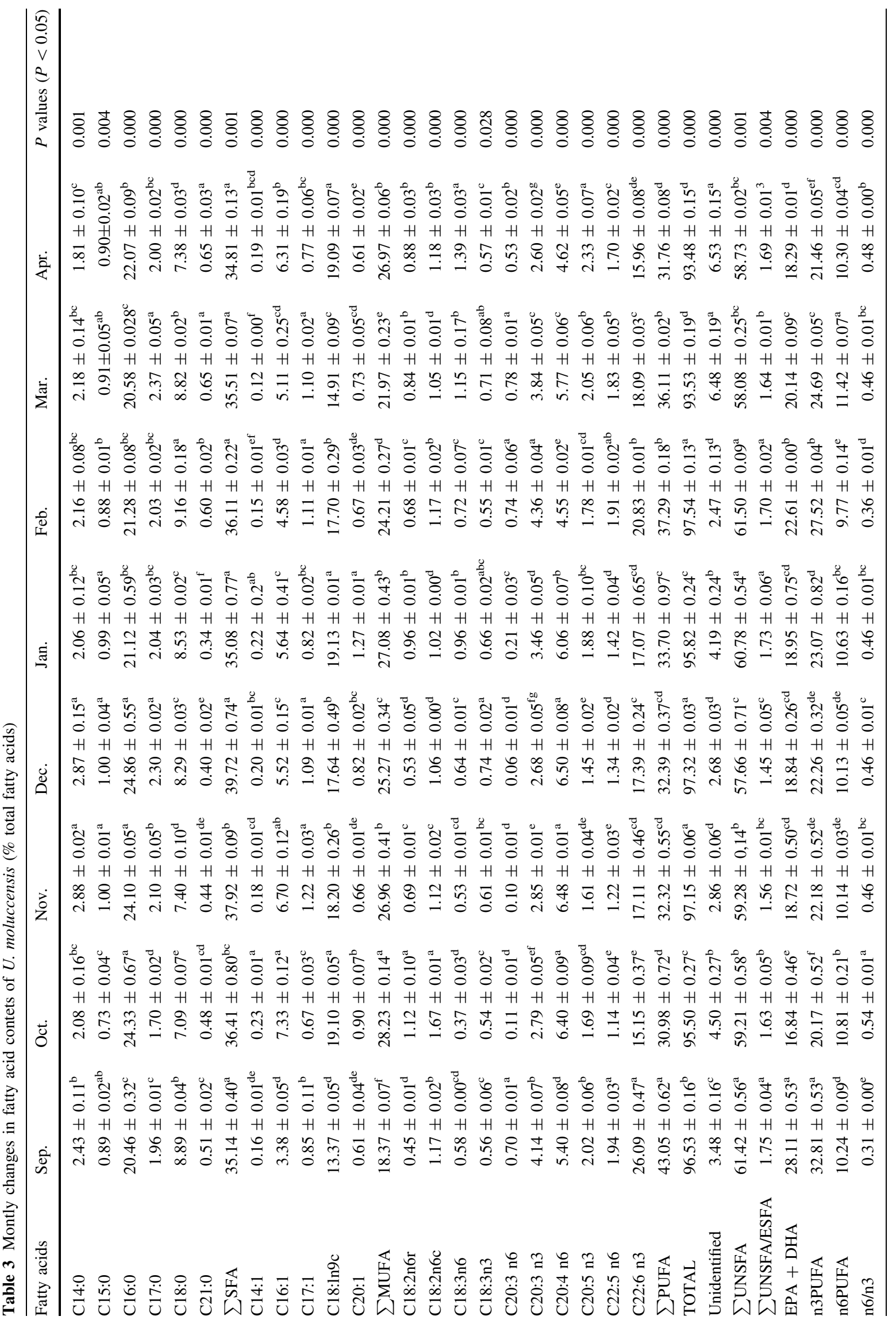




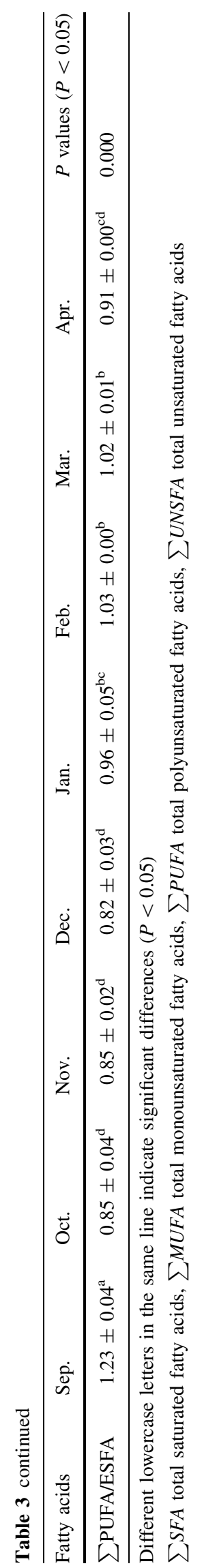


The beneficial effects of fish fat on human health are known. Polyunsaturated fatty acids (especially omega3 ) have been recognized as essential components of human food for the prevention of illness and a healthy life. There is a serious deficiency about intake of $\omega-3$ polyunsaturated fatty acid (PUFA) in human beings, for that reason to consume more foods that containing these fatty acids is recommended (Erkan 2013). In the previous studies, Guner et al. (1998) found the major fatty acids in M. barbatus were palmitic acid, palmitoleic acid, stearic acid, oleic acid, EPA, docosapentaenoic acid (DPA, C22:5n-6) and DHA. They stated that the amount of crude fat and fatty acids must be taken into account when determining the nutritional value of fish. Kalogeropoulos et al. (2004) found the major fatty acids in M. barbatus were palmitic acid, palmitoleic acid, oleic acid, EPA, and DHA. Polat et al. (2009) determined that the predominant fatty acids were palmitic acid, stearic acid, oleic acid, palmitoleic acid, EPA, and DHA in M. barbatus in all seasons, and they reported that fatty acid components were varied with season and the amount of DHA + EPA and affects consumer preferences positively. Ozogul et al. (2011) found that the fatty acids of $U$. pori and M. barbatus were seasonally changed by a number of ecological and biological effects, and EPA and DHA values were high in all seasons. Oksuz et al. (2011) found that the most abundant fatty acids in $U$. moluccensis and M. surmuletus were palmitic acid, stearic acid, oleic acid, palmitoleic acid, EPA, and DHA. They reported the amount of omega-3 more than the amount of omega-6 in both species important for human health. Erkan (2013) studied omega-3 fatty acid distribution of consumed aquatic products in Turkey and found that the most abundant fatty acids in fish fat were palmitic acid, stearic acid, palmitoleic acid, oleic acid, EPA, and DHA.

When we compared with the previous studies, it was seen that similar results were detected the most abundant fatty acids. It was also found that the unsaturated fatty acid values were between 57.66 and $61.50 \%$ (Table 3) and these values were determined similar to the previous studies. It has been determined that the fatty acid content of fish fat changes in a number of studies (Gamez-Meza et al. 1999; Luzia et al. 2003; Kuzu 2005; Polat et al. 2009; Ozogul et al. 2011). Seasonal conditions, age, size, catching area, and spawning period have been shown as the reason for the change. In our study, we were also considered that the above-mentioned factors influence the distinctions in fatty acid amounts.

\section{Amino acids}

In our study, 17 amino acids were detected in the $U$. moluccensis samples. The amino acid contents of the samples changed monthly. We found that the most abundant amino acids were lysine and leucine as essential amino acids, aspartic acid, glutamic acid, alanine, and glycine as non-essential amino acids. When the total amino acid values were examined, it was determined that the highest amount of amino acid was found in December, and the lowest amount of amino acids were found in near spawning months (April and September). Monthly changes in the amounts of amino acids were found generally significant $(P<0.05)$ (Table 4$)$. We thought that the monthly changes are caused by seasonal conditions, age, size, catching area, spawning season, and feeding conditions.

Fish are known to have high protein content and the most abundant amino acids are glutamic acid, aspartic acid, and lysine in aquatic organisms (Ozden and Erkan, 2008). In the previous studies, Kim and Lall (2000) investigated the amino acid contents of three kinds of marine flounder fish (Hippoglossus hippoglossus, Pleuronectes ferruginea, and Paralichthys olivaceus) in their study and found that the most abundant amino acids are aspartic acid, glutamic acid, glycine, leucine, and lysine. Zuraini et al. (2006) studied the amino acid contents of Channa striats, Channa micropeltes, and Channa lucius. They determined that the most abundant amino acids are glutamic acid, aspartic acid, and lysine, and they indicated that these species are rich about essential amino acids for human health and evolution. Ozden and Erkan (2008) examined the amino acid contents of three cultured species (Dicentrarchus labrax, Sparus aurata, and Dentex dentex) and determined that aspartic acid, glutamic acid, and lysine were the most abundant amino acids. They reported that aspartic acid and glutamic acid are important in enzyme solubility and protecting ionic character in enzyme activity. Adeyeye (2009), in his study, examined the amino acid contents of Clarias anguillaris, Oreochromis niloticus, and Cynoglossus senegalensis species, and he identified that glutamic acid, aspartic acid, and leucine were most common amino acids. He reported that these species are valuable amino acid sources. Erkan et al. (2010a) examined the amino acid content of Trachurus trachurus and found that the most abundant amino acids were aspartic acid, glutamic acid, and lysine. Erkan et al. (2010b) studied about the amino acid contents of Engraulis encrasicolus, Pomatomus saltatrix, Sarda sarda, M. surmelutus, and Merlangius merlangus and 


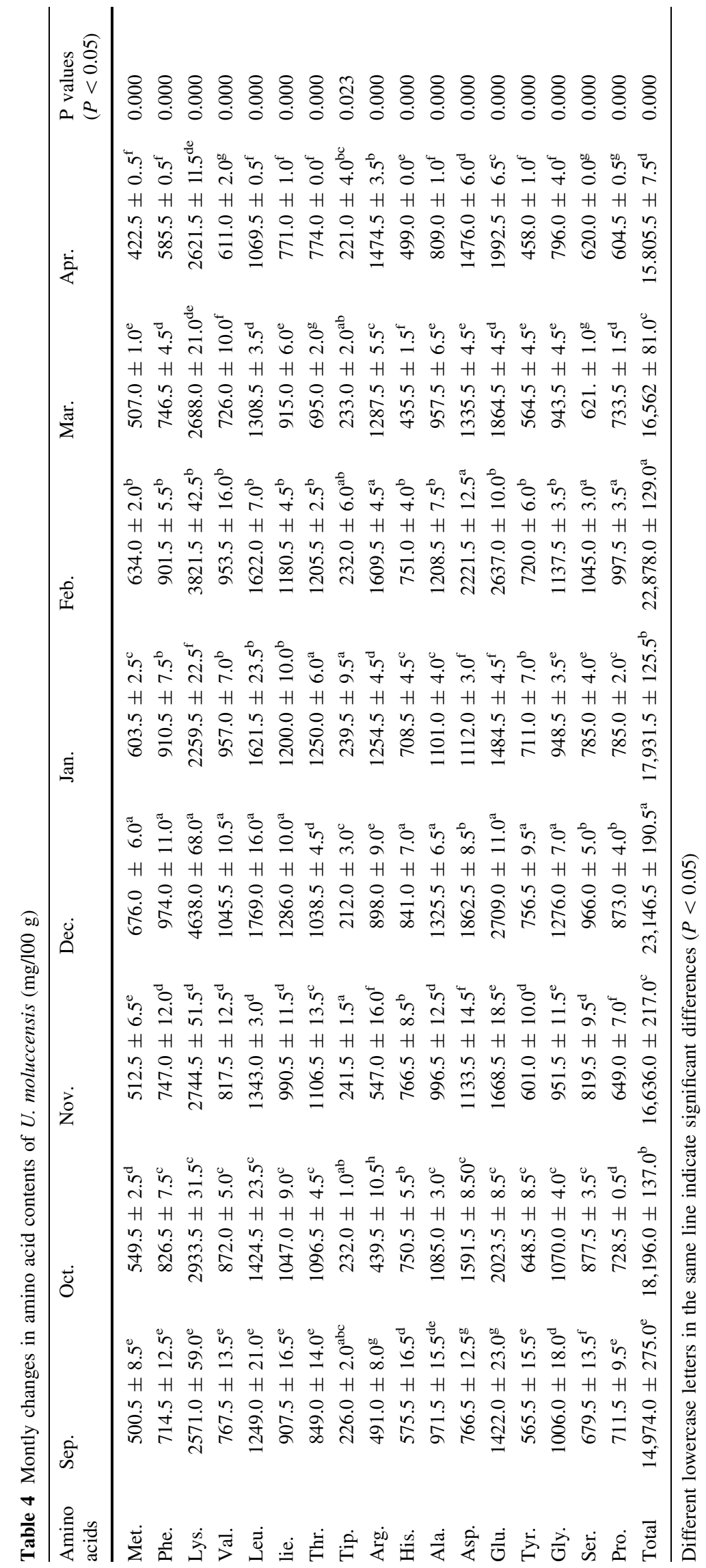


they found that lysine, leucine, arginine, glutamic acid, and aspartic acid were the most abundant amino acids. Oluwaniyi et al. (2010) studied about the amino acid contents of Clupea harengus, Scomber scombrus, Trachurus trachurus, and Urophycis tenuis species. They reported that the most abundant amino acids are glutamic acid, aspartic acid, lysine, and leucine. Zhao et al. (2010) studied about the amino acid content of Pampus punctatissimus, an important fishery source in China, and found that glutamic acid, lysine, leucine, and aspartic acid were the most abundant amino acids. Ozden and Erkan (2011) studied the amino acid contents of some fishery products and found that the amino acid values changes according to species. Peng et al. (2013), identified that the most abundant amino acids of in tuna fish (Thunnus albacares and Thunnus obesus) were aspartic acid, glutamic acid, and lysine. They stated that the named fish are a good source of nutrients in terms of glutamic acid that required for cell proliferation. Kaya et al. (2014) investigated the amino acid content of, Salmo trutta forma fario that hunting and growing on the farms, and they found that glutamic acid, aspartic acid, and lysine values were higher than other amino acids. They found that the differences in total amino acid values were generally significant $(P<0.05)$ by species and by age, and they stated that the distinction in amino acid values was due to the spawning season, the feeding conditions, and the living area. Baki et al. (2015), compared the amino acid contents of natural and cultured sea bass (Dicentrarchus labrax) in their study, and they found that the most abundant amino acids were aspartic acid, glutamic acid, leucine, and lysine. Suseno (2015) reported that the most abundant amino acids were glutamic acid, arginine, leucine, and lysine in tuna fish (Thипnus sp.). Salma et al. (2016) found that the most abundant amino acids found in mackerel (Scomber scombrus) were glutamic acid, aspartic acid, and lysine.

We did not detect any study about amino acid contents of $U$. moluccensis. For that reason, we studied the work done with different types of fish and we found similar results for the most abundant amino acids. When we compared with the previous studies, we thought that the different results may be due to seasonal, biological differences, nutritional, and environmental conditions as well as methods used for amino acid determination. In addition, Kaya et al. (2014) found significant differences in monthly amino acid values in their studies $(P<0.05)$ like us.

Oluwaniyi et al. (2010) compared the essential amino acid contents of C. harengus, S. scombrus, $T$. trachurus, and U. tenuis with the standard amino acid values of FAO/WHO (1991). They determined that the essential amino acid values of the stated species were higher than the standard amino acid values, and according to these values, indicated species are a good source of amino acid. Zhao et al. (2010) compared the essential amino acid content of $P$. punctatissimus with the reference amino acid values of FAO/WHO/UNU (1985) and determined that the essential amino acid values of $P$. punctatissimus were higher than the reference values. Peng et al. (2013) compared the amino acid content of $T$. albacares and T. obesus with the standard amino acid values of FAO/WHO (1991) and found that the essential amino acid values of these species were higher than the standard amino acid values. They reported that the the essential amino acids of stated species were above the level required by humans by age. In our study, were compared the our 8-month averages of amino acid values in U. moluccensis with the average amino acid values of FAO (2013), and we determined that U. moluccensis has significant portion of the required amount of essential amino acids (Table 5).

Table 5 Comparison of the essential amino acid contets of $U$. moluccensis with the reference essential amino acid requirement according to FAO (2013), age groups

\begin{tabular}{lllll}
\hline $\begin{array}{l}\text { Amino acids } \\
(\mathrm{mg} / \mathrm{g})\end{array}$ & \multicolumn{2}{l}{ Reference amino acid values (FAO 2013) } & $\begin{array}{l}\text { Average amino acid content of U. moluccensis } \\
\text { for } 8 \text { months }\end{array}$ \\
\cline { 2 - 5 } & $\begin{array}{l}\text { Infant } \\
(0-6 \text { month })\end{array}$ & $\begin{array}{l}\text { Child(6 month- } \\
3 \text { year })\end{array}$ & $\begin{array}{l}\text { Older child, } \\
\text { adolescent, adult }\end{array}$ & \\
\hline His. & 21 & 20 & 16 & 6.7 \\
Iie. & 55 & 32 & 30 & 10.4 \\
Leu. & 96 & 66 & 61 & 14.3 \\
Lys. & 69 & 57 & 48 & 30.3 \\
Met.+Cys. & 33 & 27 & 23 & 5.5 \\
Phe.+Tyr. & 94 & 52 & 41 & 14.3 \\
Thr. & 44 & 31 & 25 & 10.0 \\
Trp. & 17 & 8.5 & 6.6 & 2.3 \\
Val. & 55 & 43 & 40 & 8.4 \\
\hline
\end{tabular}


Compared with the previous studies (Oluwaniyi et al. 2010; Zhao et al. 2010; Peng et al. 2013), lower essential amino acid values were detected in our study. It is thought that this may be due to seasonal, biological differences, nutritional, and environmental conditions as well as methods used for amino acid determination.

\section{Conclusions}

Our study showed that the basic food components, fatty acids, and amino acid values changes by monthly and the amounts of these changes were found generally significant $(P<0.05)$. We thought that these changes were influenced by many factors such as season, biological difference (species, height, age, sex, and sexual maturity), nutrition, and environmental conditions (water chemistry, temperature, and salinity). We also concluded that $U$. moluccensis is an important food source of the basic nutrients, fatty acids, and amino acid values in all fishing seasons.

Acknowledgements We acknowledge to Suleyman Demirel University Scientific Research Projects Coordination Unit for contributions to our Project of which No. is 4451-1-15.

Open Access This article is distributed under the terms of the Creative Commons Attribution 4.0 International License (http:// creativecommons.org/licenses/by/4.0/), which permits unrestricted use, distribution, and reproduction in any medium, provided you give appropriate credit to the original author(s) and the source, provide a link to the Creative Commons license, and indicate if changes were made.

\section{References}

Adeyeye EI (2009) Amino acid composition of three species of Nigerian fish: Clarias anguillaris, Oreochromis niloticus and Cynoglossus senegalensis. Food Chem 113:43-46

AOAC (2002a) Ashes content 920.153 official methods of analyses of AOAC International 17th edn. Gaithersburg, Maryland

AOAC (2002b) Fat (total, saturated and unsaturated) in foods 996.06 official methods of analyses of AOAC International 17th edn. Gaithersburg, Maryland

AOAC (2010) Microchemical determination of nitrogen-micro kjeldahl method 960.52 official methods of analyses of AOAC International 18th edn. Gaithersburg, MD

Baki B, Gonener S, Kaya D (2015) Comparison of food, amino acid and fatty acid compositions of wild and cultivated sea bass (Dicentrarchus labrax L., 1758). Turk J Fish Aquat Sci 15:175-179. doi:10.4194/1303-2712-v15_1_19 (ISSN 1303-2712)

Bligh EG, Dyer WJ (1959) A rapid method for total lipid extraction and purification. Can J Biochem Physiol 37:911-917

Broughton KS, Johnson CS, Pace BK, Liebman M, Kleppinger KM (1997) Reduced asthma symptoms with n-3 fatty acid ingestion are related to 5-series leukotriene production. Am Soc Clin Nutr 65:1011-1017

Cakli S (2007) Su urünleri isleme teknolojisi. Ege University Press, Bornova, p 696 (ISBN: 978-975-483-761-2 Izmir, Turkey)

Canbulat Z, Ozcan T (2008) Sut urunlerinin eikosapentaenoik asit (EPA) ve dokosahekzaenoik asit (DHA) ile zenginlestirilmesi. In: Turkey 10th Food Congress 21-23 May Erzurum, Turkey, pp 713-716

Celik M, Yanar Y, Gerek A (1999) Akdeniz'de avlanan uç barbun turunun (Mullus barbatus, Mullus surmuletus, Upeneus moluccensis) besin bilesenleri yonünden karsılastırılmasi. X. In: national water products symposium 22-24 September Adana, Turkey, pp 357-362

Conquer JA, Tierney MC, Zecevic J, Bettger WJ, Fisher RH (2000) Fatty acid analysis of blood plasma of patients with Alzheimer's disease, other types of dementia, and cognitive impairment. Lipids 35:1305-1312

Dimova N (2003) RP-HPLC analysis of amino acids with UV-detection. Bulg Acad Sci 56:75-78

Ebbesson SOE, Roman MJ, Devereux RB, Kaufman D, Fabsitz RR, MacCluer JW, Dyke B, Laston S, Wenger CR, Comuzzie AG, Romanesko T, Ebbesson LOE, Nobmann ED, Howard BV (2008) Consumption of omega-3 fatty acids is not associated with a reduction in carotid atherosclerosis: the genetics of coronary artery disease in Alaska native study. Atherosclerosis 199:346-353

Erkan N (2013) Evaluation of omega 3 ( $\omega$-3) fatty acid profile of seafood products consumed in Turkey. J Fish Sci 7:194-208. doi: $10.3153 /$ jfscom. 2013020

Erkan N, Ozden O (2007) The changes of fatty acid and amino acid composition in sea bream (Sparus aurata) during irradiation process. Radiat Phys Chem 76:1636-1641

Erkan N, Selcuk A, Ozden O (2010a) Amino acid and vitamin composition of raw and cooked horse mackerel. Food Anal Methods 3:269-275

Erkan N, Ozden O, Selcuk A (2010b) Effect of frying, grilling and steaming on amino acid composition of marine fishes. J Med Food 13:1524-1531. doi:10.1089/jmf.2009.0203

Ersoy B (2006) Food composition and heavy metal contents of fishes consumed in fishing season in Northeastern Mediterranean (Adana/Karatas) Region. PhD Thesis p142 Cukurova University Institute of Applied and Natural Sciences Adana, Turkey

FAO (2013) Dietary protein quality evaluation in human nutrition. Report of an FAO Expert Consultation. Fao Food and Nutrition Paper 92 Rome. ISBN 978-92-5-107417-6 
FAO/WHO (1991) Protein quality evaluation. Report of joint FAO/WHO expert consultation. FAO food and nutrition paper 51. Italy: Rome

FAO/WHO/UNU (1985) Energy and protein requirement, WHO technical report series no. 724. Geneva, Switzerland: WHO

Gamez-Meza N, Higuera-Ciapara I, Calderon de la Barca AM, Vazquez-Moreno L, Noriega-Rodriguez J, Angulo-Guerrero O (1999) Seasonal variation in the fatty acid composition and quality of sardine oil from Sardinops sagax caeruleus of the Gulf of California. Lipids 34:639-642

Gheshlaghi R, Scharer JM, Moo-Young M, Douglas PL (2008) Corrigendum to application of statistical design for the optimization of amino acids separation by reverse-phase HPLC. Anal Biochem 383:93-102

Gulyavuz H, Unlusayın M (1999) Su Urünleri Isleme Teknolojisi. Sahin Press, Isparta, p 366 (ISBN:975-96897-0-7 Ankara, Turkey)

Gumus B, Ikız R, Unlusayın M (2009) Changes in the nutrient components after hot smoking process of red mullet (Mullus barbatus). Istanb Univ J Fish Aquat Sci 24:24-45

Guner S, Dincer B, Alemdag N, Colak A, Tufekci M (1998) Proximate composition and selected mineral content of commercially important fish species from the Black Sea. J Sci Food Agric 78:337-342

Haris WS (1997) n-3 fatty acids and serum lipoproteins: human studies. Am J Clin Nutr 65:16455-16545

Kalogeropoulos N, Andrikopoulos NK, Hassapidou M (2004) Dietary evaluation of Mediterranean fish and molluscs pan-fried in virgin olive oil. J Sci Food Agric 84:1750-1758

Kandemir S, Polat N (2007) Seasonal variation of total lipid and total fatty acid in muscle and liver of rainbow trout (Oncorhynchus mykiss W., 1792) reared in Derbent Dam Lake. Turk J Fish Aquat Sci 7:27-31

Kaya Y, Erdem ME, Turan H (2014) Monthly differentiation in meat yield, chemical and amino acid composition of wild and cultured brown trout (Salmo trutta forma fario Linneaus, 1758). Turk J Fish Aquat Sci 14:479-486. doi:10.4194/1303-2712v14_2_19

Kim JD, Lall SP (2000) Amino acid composition of whole body tissue of Atlantic halibut (Hippoglossus hippoglossus), yellowtail flounder (Pleuronectes ferruginea) and Japanese flounder (Paralichthys olivaceus). Aquaculture 187:367-373

Kuzu S (2005) The effects of different fishing seasons on the fatty acids composition of red mullet (Mullus barbatus L., 1758) captured from Iskenderun Bay. MSc Thesis p 39 Cukurova University Institute of Applied and Natural Sciences Adana, Turkey

Lovell RT (1981) Laboratory Manuel For Fish Feed Analysis and Fish Nutrition Studies. Department of Fisheries and Allied Aquacultures International Center for Aquaculture Auburn University, pp 65, Alabama

Luzia LA, Sampario GR, Castellucci CMN, Torres EAFS (2003) The influence of season on the lipid profiles of five commercially important species of Brazilian fish. Food Chem 83:93-97

Norrish AE, Jackson RT, Sharpe SJ, Skeaff CM (2000) Men who consume vegetable oils rich in monounsaturated fat: their dietary patterns and risk of prostate cancer (New Zealand). Cancer Causes Control 11:609-615

Oksuz A, Ozyılmaz A, Kuver S (2011) Fatty acid composition and mineral content of Upeneus moluccensis and Mullus surmuletus. Turk J Fish Aquat Sci 11:69-75

Oluwaniyi OO, Dosumu OO, Awolola GV (2010) Effect of processing methods (boiling, frying and roasting) on the amino acid composition of four marine fishes commonly consumed in Nigeria. Food Chem 123:1000-1006

Ozden O (2005) Changes in amino acid and fatty acid composition during shelf-life of marinated fish. J Sci Food Agric 85:2015-2020

Ozden O, Erkan N (2008) Comparison of biochemical composition of three aqua cultured fishes (Dicentrarchus labrax, Sparus aurata, Dentex dentex). Int J Food Sci Nutr 59:545-557

Ozden O, Erkan N (2011) A preliminary study of amino acid and mineral profiles of important and estimable 21 seafood species. Br Food J 113:457-469

Ozkan Y, Koca SS (2006) The efficiency of omega-3 fatty acid (fish oil) in hyperlipidemia. Firat Tip Dergisi 11:40-44

Ozogul Y, Polat A, Ucak I, Ozogul F (2011) Seasonal fat and fatty acids variations of seven marine fish species from the Mediterranean Sea. Eur J Lipid Sci Technol 113:1491-1498

Peng S, Chen C, Shi Z, Wang L (2013) Amino acid and fatty acid composition of the muscle tissue of yellowfin tuna (Thunnus albacares) and bigeye tuna (Thunnus obesus). J Food Nutr Res 1:42-45

Polat A, Kuzu S, Ozyurt G, Tokur B (2009) Fatty acid composition of red mullet (Mullus barbatus): a seasonal differentiation. J Muscle Foods 20:78-79

Rosa R, Nunes ML (2003) Nutritional quality of red shrimp, Aristeus antennatus (Risso), pink shrimp, Parapenaeus longirostris (Lucas), and Norway lobster, Nephrops norvegicus (Linnaeus). J Sci Food Agric 84:89-94. doi:10.1002/jsfa.1619

Ruiz-Capillas C, Moral A (2001) Changes in free amino acid during chilled storage of hake (Merluccius merluccius L.) in controlled atmospheres and their use as a quality control index. Eur Food Res Technol 212:302-307

Ruiz-Capillas C, Moral A (2004) Free amino acids in muscle of Norway lobster (Nephrops novergicus (L.) in controlled and modified atmospheres during chilled storage. Food Chem 86:85-91

Salma EO, Cyrine D, Nizar M (2016) Fatty acids and amino acids contents in Scomber scombrus fillets from the South East of Tunisia. Afr J Biotechnol 15:1246-1252. doi:10.5897/AJB2016.15344

Simsek A, Kırmızı S, Manasırlı M, Ozyurt G, (2009) Keserbas (Mullus Barbatus) ve cizgili barbun (Upeneus moluccensis)'un mineral ve vitamin icerikleri. XV. National Water Resources Symposium 01-04 July Rize, Turkey

Suseno SH (2015) Proximate, fatty acid and mineral composition of Tuna (Thunnus sp.) by-product from West Sumatra Province, Indonesia. Pak J Nutr 14:62-66

Tulgar A, Berik N (2012) Effect of seasonal changes on proximate composition of red mullet (Mullus barbatus) and hake (Merluccius merluccius) were catched from Saroz Bay. Res J Biol 2:45-50

Zhao F, Zhuang P, Song C, Shi ZH, Zhang LZ (2010) Amino acid and fatty acid compositions and nutritional quality of muscle in the pomfret, Pampus punctatissimus. Food Chem 118:224-227 
Zuraini A, Somchit MN, Solihah MH, Goh YM, Arifah AK, Zakaria MS, Somchit N, Rajion MA, Zakaria ZA, Mat Jais AM (2006) Fatty acid and amino acid composition of three local Malaysian Channa spp. fish. Food Chem 97:674-678

\section{Publisher's Note}

Springer Nature remains neutral with regard to jurisdictional claims in published maps and institutional affiliations. 